\title{
Insurance and the Tort System
}

\author{
Richard Lewis * \\ Professor, Cardiff Law School, Cardiff University
}

This article examines Stapleton's view that insurance has lacked influence and been no more than a 'makeweight' argument in the development of tort liability. Looking at the wider context, the article describes the overwhelming importance of insurers to the litigation system and argues that all cases are affected by insurance practice. It distinguishes the effect of insurance upon judicial fact finding, on the one hand, and the development of common law rules, on the other. It examines the ability of insurers to influence legislation relevant to the tort system. It concludes that, if account is taken of all these areas, insurance has been of vital importance to the law of tort. Without it, the system of personal injury compensation would not have survived. This conclusion is reached even though insurance is largely ignored by the great majority of tort texts.

This article examines the effect of insurance upon the law of tort and, in particular, upon the system of personal injury compensation. What is the relationship, if any, between the rules of tort law, on the one hand, and the availability of insurance, on the other? It has been argued that judges appear more ready to impose liability when insurance enables the cost of compensation to be more widely distributed. Tort rules have been said to have been developed in favour of claimants, at least in situations where they have been less able to protect themselves by taking out their own first party insurance. Others have denied that there is any consistent pattern in the law which reflects such a close relationship with insurance. This article not only considers whether the common law or statutory rules have been affected in this way, but also looks at the institutional context within which tort law is practised and insurance functions. How important are insurers to the litigation system and what influences do they bring to bear? What effect do they have upon legislation? This wider, contextual perspective, in particular, distinguishes the analysis here from the few previous examinations of the topic. 
The article begins by looking at this institutional context and the importance of insurers to the tort system in general. It then turns to an examination of the particular rules in tort. First, it sets out the general views of judges and academics concerning the effect of insurance upon the common law. Next it looks at specific areas of tort to consider whether these general views can be supported. The final section focuses upon insurers and the legislative process, and the effect insurance has had upon statute law.

\section{THE INSTITUTIONAL INFLUENCE OF INSURANCE}

There is no doubt that insurance profoundly influences the practical operation of the law of tort. Liability insurance is not merely an ancillary device to protect the insured, but is the "primary medium for the payment of compensation, and tort law [is] a subsidiary part of the process." ${ }^{\text {A }}$ Although the majority of defendants in tort are individual people, they are almost all insured. In nine out of ten cases the real defendants are insurance companies, with the remainder comprising large self-insured organisations or public bodies. Only rarely are individuals the real defendants. ${ }^{2}$ Instead policyholders cede control over their case to their insurer and thereafter

* Cardiff Law School, Cardiff University, PO Box 427, Cardiff CF10 3XJ, Wales, UK.

E Mail - LewisRK@cardiff.ac.uk.

This article draws on materials prepared by the author for a report of the European Centre of Tort and Insurance Law, based in Vienna. I am indebted to the members of that Centre and to a number of insurance representatives for their contributions to a conference on this subject held in Munich in June 2004 at the offices of the reinsurers, Munich Re. I am also grateful for the comments of my colleagues Richard Moorhead and Antonia Layard, and to Harold Luntz, Malcom Clarke, Chris Parsons, and three anonymous reviewers of this journal.

${ }^{1}$ P. Cane, Atiyah's Accidents, Compensation and the Law (London: Butterworths, $6^{\text {th }}$ ed 1999) 191.

${ }^{2}$ A recent exceptional case in which an insured motorist successfully sued a probably uninsured pedestrian is DAS International v Manley [2002] EWCA 1638. 
usually play little or no part in the litigation process. ${ }^{3}$ Insurers determine how the defence is to be conducted and, for example, commonly make admissions without the consent of the insured, ${ }^{4}$ and settle cases in spite of the policyholder's objection. ${ }^{5}$

Insurers pay out 94 per cent of tort compensation. ${ }^{6}$ Classic studies reveal that it is their bureaucracy that dictates much litigation procedure, and determines when, and for how much, claims are settled. ${ }^{7}$ It is their buildings, rather than courts of law, or even solicitors' offices, ${ }^{8}$ that are the important centres of tort practice. The number of such centres has declined recently because of company mergers and greater specialisation which has concentrated the work in particular areas. Consolidation in the liability market ${ }^{9}$ has resulted in it being dominated by only eight major companies,

${ }^{3}$ Harry Street admitted that he was once a defendant in a case but only discovered that it had been determined on appeal when he read about it in a newspaper! D. W. Elliott and H. Street, Road Accidents (London: Penguin, 1968) 209.

${ }^{4}$ T. Goriely, R. Moorhead and P. Abrams, More Civil Justice? The Impact of the Woolf Reforms on Pre-Action Behaviour (London: The Law Society and the Civil Justice Council, 2002) 90.

${ }^{5}$ However, this very wide discretion given to insurers to conduct the litigation behind the insured's back is subject to some limit as recognised in Groom v Crocker [1939] 1 KB 194.

${ }^{6}$ Report of the Royal Commission on Civil Liability and Compensation for Personal Injury, Cmnd 7054 (1978) (The Pearson Commission) vol 2 para 509.

${ }^{7}$ See H. Genn, Hard Bargaining (Oxford: Clarendon Press, 1987), D. Harris et al, Compensation for Illness and Injury (Oxford: Clarendon Press, 1984) and, in the USA context, H. L. Ross, Settled Out of Court (New York: Aldine Publishing, 1980). The major findings are supported by the few, more recent, empirical studies and, in particular, by Goriely, et al op cit note 4 . But see the critique of Genn in Dingwall et al, "Firm Handling: The Litigation Strategies of Defence Lawyers in Personal Injury Cases" (2000) 20 LS 1.

${ }^{8}$ Lord Phillips, the Master of the Rolls, has suggested even that solicitors might no longer be involved with small claims where defendants are insured, and that insurers be left to administer these claims alone. "Insurers should run small claims" [2004] Law Society Gazette, 29th April.

${ }^{9}$ Office of Fair Trading, An Analysis of Current Problems in the UK Liability Insurance Market (London: OFT659a, 2003) para 5.6. In 2002 although there were over 350 companies authorised to 
although there are more than fifty other smaller firms issuing policies. All insurers have developed highly systematised approaches to claims handling, and make extensive use of information technology. They have increasingly structured their business, and closely monitor the performance of their claims handlers and lawyers. They have reduced the number of solicitors' firms that act for them. Their standard procedures have been further refined, especially for smaller claims and "fast track" cases. Economic pressures mean that communication between the parties takes place on the telephone rather than via letters or face to face meetings, and the outcome of a claim is likely to be influenced as much by a computerised assessment as by the discretion of the claims handler involved. ${ }^{10}$ Although these generalisations about how litigation is conducted do not apply to all insurers for every type of case,${ }^{11}$ they have a great effect upon the way in which tort rules are viewed and used in practice.

Because insurers dominate the system, it is very difficult to view any tort case in isolation: each and every case is affected, no matter whether determined in court or out of it. Insurers' control over the litigation process has not been emphasised sufficiently when the effect of insurance upon individual cases and on tort rules has been considered. However, it is dealt with immediately here in order to place in a wider institutional framework the cases used as examples later in this article.

Insurers are the paymasters of the tort system: they process the routine payments and they decide which elements of damage they will accept or contest. It is unusual for them to contest liability ${ }^{12}$ and, as a result, they make at least some payment in 86 per

transact motor insurance, only 65 companies and 11 Lloyds syndicates actively did so. The ten largest motor insurers controlled two thirds of the market. ABI Response to the Greenaway Review of Compulsory Motor Insurance and Uninsured Driving (London: ABI, 2004) annex B.

${ }^{10}$ Goriely et al op cit 31 and 149.

${ }^{11}$ Dingwall et al op cit.

${ }^{12}$ Goriely et al op cit 103 found that insurers' files "contained remarkably little discussion of liability," finding it initially denied in only 20 per cent of cases. 
cent of personal injury claims made against them. ${ }^{13}$ In the great majority of cases they pay not only compensation to claimants, but also the litigation costs of both sides. However, if an action fails the claimant may become liable for costs. To avoid this, loss insurers now offer claimants, after they have been injured, a policy which promises to pay their costs in the event of an unsuccessful claim. If the claim proves successful, the premium can even be added to the damages awarded in tort. Insurers may also offer legal expenses insurance in other contexts, ${ }^{14}$ and this can affect key aspects of the litigation. ${ }^{15}$ In particular, claimants cannot easily choose their own lawyer and may be required to use one from a panel approved by the insurer. ${ }^{16}$ The clients of these solicitors may receive a different service from those freely chosen by claimants, and conflicts of interest may arise. ${ }^{17}$ Insurers thus fund the tort system, control much of the representation, and can have an interest in whatever the outcome of a claim.

Insurers determine the extent that lawyers become involved in disputes, and the tactics that are used in the proceedings. Increasingly cases are being settled at an early

\footnotetext{
${ }^{13}$ Report of the Pearson Commission above note 6, at vol 2 para 511. The relative importance to the tort system of road and industrial injuries for which insurers are most likely to be responsible has hardly changed since the Commission reported. See note 29 below.

${ }^{14}$ It is estimated that around 17 million motor policies and 15 million household policies offer 'Before the Event' Legal Expenses Insurance. Such insurers already control the litigation in 80 per cent of motor accident claims, and their market penetration is expected to continue to increase. Smith, "Panel Solicitors: the Legal Expense Insurer's Perspective” (2004) 14 (3) PI Focus 17.

${ }^{15}$ P. Fenn, A. Gray and N. Rickman, The Impact of Sources of Finance on Personal Injury Litigation (2002) Lord Chancellor's Department No 7/02. P. Abrams, In Safe Hands? Funding Litigation by Legal Expenses Insurance (London: University of Westminster, 2002).

${ }^{16}$ Blundell, "Free to Choose? BTE Legal Expenses Insurance and Freedom of Choice” [2004] JPIL 93. It is feared that all road accident litigation will be dealt with by no more than a hundred solicitors firms nationwide. Lawson, "BTE Insurance - a Threat to the Profession or New Opportunities?"
} (2004) 14 (3) PI Focus 17.

${ }^{17}$ Abrams op cit chapters 8 and 9. 
stage, and without resort to the issue of court documents. ${ }^{18}$ Insurers decide, in particular, whether a case merits the very exceptional treatment of being taken to a court hearing. ${ }^{19}$ In effect, they allow trial judges to determine only one per cent of all the claims made. Only a few of these are appealed with the result that the senior judiciary are left to adjudicate upon a small fraction of what are, by then, very untypical cases. Whether an appeal court is to be given an opportunity to examine a point of tort law may depend upon the insurer for, if it serves the insurer's purpose for doubt to remain, the claimant can be paid in full and threatened with a costs award if the action is continued. ${ }^{20}$ In this sense tort principles themselves have been shaped by

${ }^{18}$ Goriely et al op cit at 159 found that almost all parties agreed that, after the Woolf reforms of civil procedure, cases were now more likely to be resolved without court involvement. Major insurers estimated that, because of earlier settlement, the number of cases disposed of only after the issue of formal proceedings had declined by a third. As a result, for example, Axa insurance company announced in September 2004 that it had reduced by half the number of law firms defending its cases. Even in the past, according to the Pearson Commission op cit vol 2 table 12, 86 per cent of cases were settled without a writ being issued.

${ }^{19}$ Before being set down for trial 98 per cent of cases are settled, and many more are concluded before any hearing takes place. The Pearson Commission op cit vol 2 table 12. Similarly P. Pleasence, Personal Injury Litigation in Practice (London: Legal Aid Board Research Unit, 1998) at 12 reveals that only 5 out of the 762 "ordinary" cases with costs of less than $£ 5,000$ that were studied went to trial. Earlier, Harris et al op cit had suggested that the figure might be as high as 3 per cent. However, even in cases involving very substantial awards of damages - $£ 150,000$ or more paid by insurers in 1987 and 1988 - only ten per cent of payments were the result of formal court orders, and most of these related to children or patients for whom court approval of their settlements is required. P. Cornes, Coping with Catastrophic Injury (Edinburgh: Rehabilitation Studies Unit, 1993) 20.

${ }^{20}$ As recognised in Davis v Johnson [1979] AC 264 at 278. But see the failed attempt to prevent the House of Lords considering important causation issues in relation to asbestos liability in Fairchild $v$ Glenhaven Funeral Services Ltd [2002] 1 AC 32 discussed by Oliphant in H. Koziol and B.C. Steininger (eds), European Tort Law 2002 (Vienna: Springer, 2003) 148, and in [2002] 12 (3) Association of Personal Injury Lawyers Newsletter 19. 
and for insurers, even though there has been a significant growth in the power of claimant lawyers in the last twenty years. ${ }^{21}$

Insurers' influence upon settlements is even more pronounced than it is upon decided cases. For the lawyer asked by his client to advise on the merits of a claim it is the realities of the litigation system that are of concern rather than the formal rules of law. Practitioners would agree with the key analysis of Ross ${ }^{22}$ that the textbook rules of tort are often transformed when they come to be used in the system in three ways: firstly, they are simplified; secondly, they are made more liberal; and thirdly, they are made more inequitable. Simplification occurs because the rules are too uncertain when applied to the individual facts of particular accidents. For reasons of cost and administrative efficiency, insurers have been forced to substitute other criteria for the strict tort rules. Mechanical rules of thumb - such as the car running into the back of another always being found the one at fault - replace any detailed investigation into blame. There is neither the time nor resources to instruct experts to analyse the scene of each road accident and precisely measure its effect upon the individual claimant. Cases are disposed of on the basis of paperwork alone, and this may bear only a limited relationship to what actually occurred. The result of the cost pressures upon insurers is that more claims succeed than the strict rules of tort would allow. Many insurers pay something for claims which, on full investigation, would be without foundation. As a result

\footnotetext{
${ }^{21}$ Claimant lawyers are now much more likely to be specialists and work in larger and much better organised firms than in the past. Relying upon Law Society figures, Goriely et al op cit note 4 at 25 note that even before April 2000 (when almost all legal aid was abolished for personal injury claims) solicitors were becoming increasingly specialised, and fewer firms were "dabbling" in such work. The founding of the Association of Personal Injury Lawyers in 1990 and its subsequent activity reflects the increasing abilities and resources of claimant lawyers. Melville Williams, “A. P. I. L.” (1991) 19 Civil Justice Q 103. The Association now has over 5,100 members, employs 29 people, and has a turnover of $£ 1.73$ million. It is extremely well organised, and has its own Press, Parliamentary and Research officers as well as other administrators. See APIL, Annual Report and Accounts 2003.

${ }^{22}$ H. L. Ross op cit.
} 
“... wherever there is insurance there is ... a closer approximation to the objectives of social insurance in fact than the doctrines of tort law would lead one to suppose." 23

However, this liberality is but part of a system which overall is weighted in favour of insurers and results in much inequality. Indeed the case often used to illustrate the general inequalities in the legal system involves a "one-shotter" accident victim suing a "repeat player" insurer. ${ }^{24}$ Delay, uncertainty, financial need and other pressures cause claimants to accept sums much lower than a judge would award. The eagerness of claimants and their solicitors to get something from the system is reflected in the fact that they have been found to be very keen to accept any formal offer made to them by the "risk neutral" insurer. ${ }^{25}$ Those who can withstand the pressures of litigation do better than those who cannot, with the result that those from a particular class or background are more likely to succeed. ${ }^{26}$ Those who suffer most are the severely injured. Although in the greatest need, they will find their high value claim scrutinised in detail and processed very differently from the average case which typically involves but a minor upset and little, if any, financial loss. Those seriously injured are much less likely to receive "full" compensation than those suffering minor injuries who, for a variety of reasons, are likely to be over-compensated. ${ }^{27}$ The overall result of the

${ }^{23}$ F. V. Harper and Fleming James, The Law of Torts (Boston: Little Brown \& Co, 1956) s 13.7.

${ }^{24}$ The seminal article is Galanter, "Why the 'Haves' Come Out Ahead” (1974) 9 Law and Society Rev 95. However, Dingwall et al op cit emphasise that not all defendants in personal injury cases are "repeat players" and they should not be treated as a homogenous group. Other limits of the article were examined in an anniversary special issue in (1999) 33 Law and Society Rev 795.

${ }^{25}$ According to D. Harris et al op cit table 3.3 claimants' solicitors used to accept the first formal offer made to them in two out of three cases. More recently Goriely et al op cit at 154 found more incidence of bargaining, although a third of cases still settled after only one offer, almost two thirds after two and ninety per cent after three.

${ }^{26}$ Ross op cit.

${ }^{27}$ D. Dewees, D. Duff, and M. Trebilcock, Exploring the Domain of Accident Law: Taking the Facts Seriously (Oxford: OUP, 1996) 19. P. A. Bell and J. O'Connell, Accidental Justice: The Dilemmas of Tort Law (New Haven: Yale University Press, 1997) 63 - 66. 
settlement system is that rough and ready justice is dispensed, much influenced by insurance company personnel and procedures, and driven by the needs of the insurance industry. The system produces arbitrary results and bears only a limited relationship to the portrayal of justice contained in the traditional tort textbook.

The importance of insurers to the tort system is reflected in the fact that the claims which are brought closely match the areas where liability insurance is to be found. Thus road and work accidents predominate partly because those are the two major areas where tort insurance is compulsory. ${ }^{28}$ They constitute 86 per cent of all the claims brought for personal injury. ${ }^{29}$ They dominate the practice of tort even though they are relatively minor causes of disability and incapacity for work. ${ }^{30}$ Those suffering injury in areas not covered by insurance are extremely unlikely to obtain compensation. According to one study, whereas 1 in 4 road accident victims and 1 in

${ }^{28}$ The other miscellaneous areas of compulsory insurance and the lack of coherent policy behind them are traced in Lewis, "The Duty to Insure" (2004) 19 (2) J Ins Research \& Practice 57. See also Parsons, “Employers Liability Insurance - How Secure is the System?” (1999) 28 Ind LJ 109.

${ }^{29}$ Compensation Recovery Unit figures for 2003-04, with motor comprising 48 per cent of the total and employer liability 37 per cent. Similarly Datamonitor, UK Personal Injury Litigation 2003 fig 5. The nature of litigation in this respect has hardly changed for the Pearson Commission total figure of 88 per cent was only 2 per cent more than that reported twenty five years later. Op cit vol 2 table 11 . Atiyah suspected that the relative proportion of claims had not changed. P. S. Atiyah, The Damages Lottery (Oxford: Hart Publishing, 1997) 99.

${ }^{30}$ Harris op cit table 2.1 found that the most common accidents were those in the home, or suffered in the course of leisure activities or in playing sport, and yet very few of these resulted in any damages award. Although work and transport injuries dominate the tort system they comprise only about half of all accidents according to Pearson op cit vol 2 table 57, and in Australia less than a fifth according to H. Luntz and D. Hambly, Torts: Cases and Commentary (Sydney: Butterworths, $5^{\text {th }}$ ed 2002) 4. Datamonitor op cit 79 estimate that there were 7.8 million accidents in the home in 1999 of which only 0.5 per cent potentially could result in a successful tort claim. 
10 work accident victims gain compensation from tort, only 1 in 67 injured elsewhere do so. ${ }^{31}$

The scope of the tort system is affected not only by those areas where liability insurance has been made compulsory, but also by the existence of alternative sources of compensation. What opportunities are there for resort to either welfare payments from public insurance, or policy monies from first party private insurance? The interrelationship of compensation systems cannot be discussed in detail here, ${ }^{32}$ but a couple of examples will suffice to demonstrate the potential effects of other insurance systems upon tort. The first example is a historical one and, in practice, resulted in the abandonment of tort law for the great majority of work injuries. It derives from the 'election' rule whereby workers injured in the course of their employment had to choose either to sue in tort or to claim private insurance benefits on a no-fault basis from their employer. They could not obtain these insurance benefits and pursue an action in tort. For a variety of reasons employees overwhelmingly opted, or were pressed into receiving the no-fault benefits, ${ }^{33}$ leaving the tort system with a very limited role to play in the industrial field. ${ }^{34}$ Although this 'employer privilege'

${ }^{31}$ The Pearson Commission op cit vol 1 table 5. The study reveals that only 6.5 per cent of all accident victims incapacitated for three days of more are compensated by the tort system. However, if only serious injuries are considered tort becomes much more important. Where an accident causes incapacity for work for six months or more, almost a third of claimants receive tort damages. Harris et al op cit made similar findings concerning the limited importance of the tort system to accident victims in general. The significance of tort is reduced tenfold if account is taken of those suffering disablement not from accidents alone but from all causes, including congenital illness and disease. P. S. Atiyah, The Damages Lottery (Oxford: Hart Publishing, 1997) 100.

${ }^{32}$ For a recent example see U. Magnus (ed), The Impact of Social Security Law on Tort Law (Vienna: Springer, 2003).

${ }^{33}$ W. A. Dinsdale, History of Accident Insurance in Great Britain (London: Stone and Cox, 1954) 161. For judicial criticism of the "deplorable" and "extremely shabby" tactics used by insurers see Deane v H. F. Edwards \& Co (1941) 34 BWCC 183.

${ }^{34}$ P. W. J. Bartrip, Workmen's Compensation in Twentieth Century Britain (Aldershot: Avebury, 1987) chap 10 . 
continues in North America, a few European countries, and increasingly in Australia, it was abolished in the UK in $1948 .^{35}$ Tort claims for work accidents have since flourished, and now constitute over a third of all the actions brought. ${ }^{36}$

A second example of the influence of insurance upon the extent to which resort is had to litigation involves private agreements between insurers to abandon the tort system in respect of certain losses. This may take various forms, ${ }^{37}$ but the agreement which has come to public attention is the so called 'knock for knock' arrangement in relation to motor accidents. ${ }^{38}$ Although more reluctant to do so in recent years, motor insurers have set up a series of agreements with other insurers which have similar risk profiles concerning the extent to which they will litigate. In advance of any accident involving claimants covered by both first and third party insurance, they agree firstly, that each will indemnify the property damage suffered by its own policyholder; and secondly, that they will not use the tort system to reclaim any of this loss from the other party even if they were clearly responsible for the damage. Where an insurer suffers a loss as a result of this arrangement, it hopes to make up for it in a later case. Overall, insurers expect that matters will even themselves out. These agreements are made in order to avoid the excessive cost and uncertainty that would be involved if insurers were forced to use the tort system for all small claims. They result from the inter-relationship of first party insurance with the tort system.

This influence of insurance upon the general pattern of tort liability is matched by its effect upon the level of compensation awarded. The principles upon which damages are assessed implicitly recognise that it is a company with a deep pocket that will pay and not an individual. Although most awards in tort are for very limited sums

\footnotetext{
${ }^{35}$ Law Reform (Personal Injuries) Act 1948.

${ }^{36}$ Compensation Recovery Unit figures for 2003 - 04. Contrast the somewhat lower proportion cited by Datamonitor, UK Personal Injury Litigation 2003 fig 5.

${ }^{37}$ Lewis, “Insurers' Agreements not to Enforce their Strict Legal Rights” (1985) 48 Modern L Rev 275.

${ }^{38}$ First judicially recognised as long ago as Morley v Moore [1936] 2 KB 359.
} 
- little more than $£ 2,500^{39}$ - there are very few individuals who could afford to pay the amounts required in serious injury cases. The justice of the case never merits an investigation into the limited means of the average person found liable because that person will not have to pay. If it were not for insurance there would be little hope of restoring the claimant to the pre-accident position in a serious injury case. It is doubtful whether we would even wish to attempt to place full responsibility for the damage on most defendants. The very nature of the tort system would have to change. Without insurance, it is probable that tort liability itself could not survive. ${ }^{40}$

These facts about the tort system have been empirically established in a series of studies, ${ }^{41}$ but gain little prominence in tort textbooks. ${ }^{42}$ In spite of students being left

${ }^{39}$ This is the median figure in the survey of 81,000 cases receiving legal aid and closed in 1996 - 97 in P. Pleasence, Personal Injury Litigation in Practice (London: Legal Aid Board Research Unit, 1998) 40 fig 3.17. In 70 per cent of successful cases the damages were less than $£ 5,000$, although the overall average was $£ 11,000$. Fenn and Rickman, “Costs of Low Value Liability Claims 1997-2002” report average damages of only $£ 3,000$ for employers liability accident claims, although this study of almost 100,000 cases related only to claims for less than $£ 15,000$. See http://www.dca.gov.uk/majrep/claims/elclaims.htm . Datamonitor op cit 81 reports the average general liability personal injury claim in 2002 cost $£ 4,407$. In evidence to the Law Commission in 1993 the Trades Union Council noted that the average sum obtained in the 150,000 union-backed cases in 1991 was under $£ 2,000$.

40 J. G. Fleming, The American Tort Process (Oxford: Clarendon Press, 1988) 21. Without insurance, the system "would long ago have collapsed under the weight of the demands put on it and been replaced by an alternative, and perhaps more efficient system of accident compensation.” J. G. Fleming, The Law of Torts (Sydney: LBC Information Services, $9^{\text {th }}$ ed 1998) 13.

${ }^{41}$ Extensively referenced in D. Dewees, D. Duff, and M. Trebilcock, Exploring the Domain of Accident Law: Taking the Facts Seriously (Oxford: OUP, 1996). But see Saks, "Do We Really Know Anything about the Behaviour of the Tort Litigation System - and Why Not?” (1992) 140 U Pennsylvania L R 1147.

${ }^{42}$ The major exception being P. Cane, Atiyah's Accidents, Compensation and the Law (London: Butterworths, $6^{\text {th }}$ ed 1999) especially chap 9 . There is little useful discussion in the many student and practitioner texts with the exception of M. Jones, Textbook on Torts (Oxford: OUP, $8^{\text {th }}$ ed 2002) s.1.3 and S. Deakin, A. Johnson and B. Markesinis, Tort Law (Oxford: OUP, $5^{\text {th }}$ ed 2003). Although J. G. 
in ignorance, it cannot be denied that insurance in this context is fundamental to the general operation of the tort system. "Insurance 'technology' underlies the whole practice of tort law." ${ }^{43}$ Over fifty years ago one writer concluded that the doctrines of tort law

"... are horse and buggy rules in an age of machinery; and they might well have gone to the scrap heap some time ago had not the tremendous growth of liability insurance and the progressive ingenuity of the companies made it possible to get some of the benefits of social insurance under - or perhaps in spite of - the legal rules."

It is to the rules that we now turn.

\section{THE VIEWS OF JUDGES AND ACADEMICS OF THE EFFECT OF INSURANCE}

In the first part of this article we concluded that insurers have had a major effect upon the general operation of the tort system. However, there is much more doubt about the extent that insurance can be shown to be a factor taken into account to determine the outcome of individual cases. To what extent have facts been interpreted to fit the established basis for liability, and the result thus manufactured perhaps for the benefit an uninsured claimant? More significant for the academic tort lawyer is the suggestion that, rather than the facts, it is the rules themselves that have been changed to accommodate the insurance position.

Fleming, The Law of Torts (Sydney: LBC Information Services, $9^{\text {th }}$ ed 1998) 13 regards insurance as the cause of a vast expansion in liability and this "pervasive trend runs like a golden thread" throughout the book, he gives few examples of insurance having a direct effect. There are few insurance textbooks compared to tort, but they similarly avoid specific examination of the effect of insurance on tort liability. A notable exception is the excellent section in M. Clarke, Policies and Perceptions of Insurance (Oxford: Clarendon Press, 1997) chap 8.

${ }^{43}$ J. Steele, Risks and Legal Theory (Oxford: Hart Publishing, 2004) 36.

${ }^{44}$ Fleming James, “Accident Liability Reconsidered: The Impact of Liability Insurance” (1948) 57 Yale LJ 549 at 569. 
Why might this be done? We need not examine the economic, political and social arguments in detail here. However, in simple terms, some have argued that liability may more readily be imposed if the tort action is seen only as a means of compensating needy individuals, and the defendant is merely a conduit to an insurance fund and a means of distributing the cost of the injury to a wider pool. Conversely, if the claimant has his own insurance for the loss caused, his needs are less and liability may then be denied. 'Who is insured?' and 'who is in the better position to insure?' have thus been seen by some as key questions in determining liability issues. Whether it is economically more efficient for a loss to be met from first party insurance rather than from liability insurance via a tort claim raises wide issues. However, it is sufficient here to note that the relative insurability of the parties has been argued to be relevant when determining whether liability should be imposed.

\section{Judicial views}

In the past it was almost unknown for judges to examine or even acknowledge the existence of insurance relating to a claim, and it remains extremely unusual for them to do so. They have occasionally asserted that insurance has had no direct effect upon them, stating that it "is not the function of a court of law to fasten on the fortuitous circumstance of insurance to impose a greater burden" on the defendant than would otherwise be the case. ${ }^{45}$ However, their general silence about such matters has not prevented speculation about whether the wider arguments relating to insurability are having an unacknowledged effect. It is difficult for judges to discuss insurance factors openly - even if they consider them relevant - because they give rise to wide ranging policy considerations. In addition, if insurance were openly recognised as a determining factor, judges could be accused of deciding cases on the basis of the

\footnotetext{
${ }^{45}$ Viscount Simonds in Davie v New Merton Board Mills [1959] AC 604 at 627. Similar comments were made by the same judge in Lister v Romford Ice Storage Co Ltd [1957] AC 555 at 576, and by Lord Bridge in Hunt v Severs [1994] 2 AC 350 at 393. Lord Wilberforce in Morgans v Launchbury [1973] AC 127 at 137 thought it dangerous and irresponsible for judges to alter the basis of liability without knowledge about the impact upon the insurance system.
} 
parties' means alone, and the idea that a rich or protected litigant must always lose to a poor or needy one is too simplistic to contemplate.

As an exception to the general rule, Lord Denning was more prepared to examine the insurance background to disputes but even he did so only occasionally. Most famously, in a case over thirty years ago involving a learner driver being sued by her instructor for negligent driving, he suggested that the presence of liability insurance could determine the standard of care to be applied. He thought that the skill of a fully qualified driver could be required from the learner driver partly because she carried liability insurance:

"Parliament requires every driver to be insured against third party risks. The reason is so that a person injured by a motor car should not be left to bear the loss on his own, but should be compensated out of the insurance fund. The fund is better able to bear it than he can. But the injured person is only able to recover if the driver is liable in law. So the judges see to it that he is liable, unless he can prove care and skill of a high standard .... Thus we are ... moving away from the concept: 'No liability without fault.' We are beginning to apply the test: 'On whom should the risk fall?' Morally the learner driver is not at fault; but legally she is liable to be because she is insured and the risk should fall on her." $" 46$

Two years later he returned to the theme, pointing out that it was damages as well as liability that had been influenced:

"The damages are expected to be borne by the insurers. The courts themselves recognise this every day. They would not find negligence so readily - or award sums of such increasing magnitude - except on the footing that the damages are to be borne, not by the man himself, but by an insurance company.", 47

Although the law reports contain no other statements as explicit as these, in the last fifteen years or so they have made increasing reference to insurance. Judges are more

\footnotetext{
${ }^{46}$ Nettleship v Weston [1971] 2 QB 691 at 699.

${ }^{47}$ Morris v Ford Motor Co Ltd [1973] QB 792 at 798.
} 
prepared than in the past to discuss wider policy issues, ${ }^{48}$ and these have sometimes included insurance aspects. ${ }^{49}$ Within this broader framework judges have referred to distributive justice whereby account is taken of the effects of a decision beyond the immediate parties to the dispute. In a recent lecture Lord Steyn stated:

"The primary aim of tort law is the pursuit of corrective justice. It requires somebody who has harmed another without justification to indemnify the other. There is, however, another perspective, namely considerations of distributive justice. It concentrates on the place of the plaintiff and the defendant in society.... Not surprisingly, our courts have not shut their eyes to such considerations: the insurance position of the parties has sometimes been treated as relevant."

Insurance, therefore, may be taken into account but only "sometimes". It is difficult to forecast when and with what effect. There is considerable uncertainty.

\section{Commentators' views}

A Realist perspective upon the judicial role emphasises the importance of underlying policy considerations as against the formalist reasoning contained in the judgements themselves. Traditional judicial silence on insurance has provided a vacuum which a few tort scholars have sought to fill. Some have drawn inferences about the influence of insurance in spite the reasons expressly given in the judgements, whereas others have rejected such causal connections. There has been a

${ }^{48}$ K. Malleson, The New Judiciary: The Effects of Expansion and Activism (Aldershot: Dartmouth, 1999), R. Stevens, The English Judges: Their Role in the Changing Constitution (Oxford: Hart, 2002), M. Kirby, Judicial Activism (London: Sweet and Maxwell, 2005, forthcoming).

${ }^{49}$ For an Australian context see Gill, “The Expansion of Liability and the Role of Insurance - Who's the Chicken?” [1999] International J of Insurance Law 27.

${ }^{50}$ Lord Steyn, "Perspectives of Corrective and Distributive Justice in Tort Law"" (2002) 23 Irish Jurist 1. Similarly, in McFarlane v Tayside Health Board [2000] 2 AC 59 at 83 he described the duty of care as "a mosaic in which the principles of corrective and distributive justice are interwoven." Lord Hoffmann said that corrective justice “... has been abandoned in favour of a cautious pragmatism” in Frost v Chief Constable of South Yorkshire Police [1999] 2 AC 455 at 502. For the most recent discussion of distributive justice in an insurance context see J. Steele, Risks and Legal Theory (Oxford: Hart Publishing, 2004). 
sharp division in views. On the one hand, there are those who argue that the "hidden hand" of insurance has had a great effect, ${ }^{51}$ courts are said frequently "to treat tort as a compensation and loss-spreading scheme, via the pervasive phenomenon of liability insurance." 52 Judges may even be influenced without knowing it because insurance "acts as a stimulus to decision-making whether or not the decision-maker is consciously aware of it." ${ }^{53}$ The result, according to Cane, is that "there can be little doubt that the development of the law has been influenced by the growing prevalence of liability insurance." ${ }^{54}$ Another textbook agrees:

"... [T] here is no denying the fact that, as a result of modern insurance practices, the notions of 'duty' (and causation) are at times used to conceal insurance dictates and the term 'negligence' is employed in contexts where the defendant could not humanly have avoided the accident in question." $" 55$

Even if the rules themselves have not directly been affected, insurance may thus "invisibly" influence the result in a particular case. ${ }^{56}$

${ }^{51}$ J. G. Fleming, op cit 13 : “[W]hile in theory insurance follows liability, in experience insurance often paves the way to liability. In short it is the hidden persuader." It plays its role "from a hidden position behind the scenery" according to Cousy, "Tort Liability and Liability Insurance: A Difficult Relationship" in H. Koziol and B. Steininger (eds) European Tort Law 2001 (Vienna: Springer, 2002).

${ }^{52}$ Morgan, “Tort, Insurance and Incoherence” (2004) 67 Modern L Rev 384 at 392.

${ }^{53}$ Davies, "The End of the Affair: Duty of Care and Liability Insurance" (1989) 9 LS 67 cf B. Cardozo, The Nature of the Judicial Process (New Haven: Yale University Press, 1921) 12: "It is often through these subconscious forces that judges are kept consistent with themselves, and inconsistent with one another."

${ }^{54}$ Op cit note 1 at 203.

${ }^{55}$ S. Deakin, A. Johnson and B. Markesinis, Tort Law (Oxford: OUP, $5^{\text {th }}$ ed 2003) 3.

${ }^{56}$ Fleming James, “Accident Liability Reconsidered: The Impact of Liability Insurance” (1948) 57 Yale LJ 549 at 551. 
On the other hand, others have argued that the effect of insurance has been exaggerated and that in fact it has had little effect on tort rules themselves. Prosser's view, over thirty years ago, was that

"While liability insurance undoubtedly has had an effect, it is difficult to escape the impression that all this has been very much overstated. A dispassionate observer, if such a one is to be found in this area, might ... conclude that the 'impact' of insurance upon the law of torts has been amazingly slight; that most of the changes that have been pointed out are due to other causes...."57

Similarly, Clarke today argues that influence - in the sense that the law has been tailored to fit the insurance position - is scarcely to be seen at all. ${ }^{58}$

In examining these issues Stapleton has written a key article. ${ }^{59}$ She argues that any causal link between the development of insurance and the expansion of tort liability must be viewed with caution. Echoing the words of Prosser, she concludes that when courts refer to insurance they do so only as a 'makeweight' factor after it has been decided to impose liability for other reasons. She points to tort rules which appear to be entirely unaffected by insurance factors, and argues that commentators have used the argument selectively to explain certain developments while ignoring other areas. There has been no fundamental shift in the formal basis of tort law such as might have been expected if insurance were to provide a new foundation for its development. The formal rules still usually require proof of fault, and the failure to move decisively towards a stricter liability is evidence of the limited effect of insurance. Finally, Stapleton is concerned that if attention is paid only to insurability, the potential deterrent or corrective role of tort will be suppressed. Even though many will not share the belief that, in practice, tort has much effect in controlling behaviour or achieving deterrence, and many may doubt that the tort system produces results which

${ }^{57}$ W. L. Prosser, Law of Torts (West Publishing Co: St Paul, $4^{\text {th }}$ ed 1971) 547. In his evaluation of Prosser, White argues that, although insurance was not the primary factor, it did stimulate the growth of strict liability. G. E. White, Tort Law in America (Oxford: OUP, 1980) 172.

\footnotetext{
${ }^{58}$ M. Clarke, Policies and Perceptions of Insurance (Oxford: Clarendon Press, 1997) 283.

${ }^{59}$ Stapleton, “Tort, Insurance and Ideology” (1995) 58 Modern L R 820.
} 
have such a high claims to justice, nevertheless they will agree that it is a mistake to place too much emphasis upon tort law as a means of compensation. Tort is but one of a number of compensation options available, or which might be developed. ${ }^{60}$

In spite of her criticisms, Stapleton acknowledges that insurance is clearly relevant to "the operation of tort law in daily life." This includes its effect upon who sues, and the dynamics of the settlement process. In addition, she agrees that judges are fully aware that it is the insurer who pays, and, at a very general level, it is likely that courts have been influenced. However, she casts doubt upon more specific claims that link the expansion of tort liability with the availability of liability insurance.

Although there is much to agree with here, ${ }^{61}$ it is not always easy in practice to draw the distinctions upon which the analysis relies. In particular, it can be difficult to isolate individual decision making from the institutional framework of the tort system. Stapleton accepts, but does not expand upon, the influence of insurance on the "operation of tort law in daily life." This was discussed in more detail at the beginning of this article where it was suggested that insurers' control and administration of the tort system affects all claims. In particular, later in this article it is argued that the pervasive influence of insurance becomes clearer if the focus changes from establishing liability to assessing damages. Restoring the victim to the pre-accident position becomes inconceivable in serious injury cases in the absence of a mechanism

${ }^{60}$ Sugarman, "Personal Injury and Social Policy - Institutional and Ideological Alternatives" in N. Mullany and A. M. Linden (eds), Torts Tomorrow (Sydney: LBC Information Services, 1998). One such alternative was given in S. Sugarman, Doing away with Personal Injury Law (New York: Quorum, 1989), and another in T. Ison, Compensation Systems for Injury and Disease: The Policy Choices (Toronto: Butterworths, 1994). These solutions can be contrasted with, for example, the first party insurance proposals of P. S. Atiyah, The Damages Lottery (Oxford: Hart Publishing, 1997), and the reform suggestions noted by Dewees et al op cit.

${ }^{61}$ In criticising the article, Morgan op cit does not reflect upon the subtleties in Stapleton's argument contained in the previous paragraph, and rather than engaging with the detailed analysis of the caselaw she presents, relies upon only two recent cases to substantiate his argument that courts "frequently" take insurance into account. Unfortunately, this is the very generalisation to which Stapleton objects. 
for distributing the cost of doing so. In this sense each award of substantial damages reflects the importance of insurance to the tort system. Finally, even if we accept that tort rules themselves have not been changed substantially by insurance we might still conclude that, in determining the facts of a particular case, judges have been "invisibly" affected by knowledge of the insurance position. The "sympathetic factor" at trial is known to litigators, and is what Clarke calls the "magnetic effect" of money whereby the result is influenced by any deep pocket in a case. ${ }^{62}$ Fitting the facts, rather than the law, to the insurance position limits the value of Stapleton's analysis.

\section{Conclusion}

All commentators therefore agree that insurance undoubtedly has had some influence upon tort; it is only the extent of this influence that is open to question. Here it is argued that that influence has been substantial. Not only has insurance had a profound effect upon the operation of the claims system in general, but it has also influenced individual cases. Practitioners are aware that insurance is one of the factors that may determine the inferences to be drawn from the facts of the case. It competes with corrective justice and the moral basis of the fault principle in this regard to produce a tension which cannot be reconciled. Sometimes the insurance factor and the need for compensation will triumph, and negligence will be found where none existed; but occasionally the absence of fault will prevent the claim from succeeding. The morality of the fault principle still has a great effect upon determining liability, but the general effect of insurance becomes more pronounced when damages for serious injury are being assessed.

Whether the rules of tort themselves have been changed to reflect insurance is more difficult to establish. On the one hand, it is certainly true that the foundations of tort remain largely unchanged. Formally, liability still depends upon proof of fault and, even where rules have been revised more in favour of claimants, it is too easy to suggest that insurance is the cause. On the other hand, some judges have acknowledged that they have concerned themselves with who has the deeper pocket,

\footnotetext{
${ }^{62}$ Op cit 273.
} 
or who was in the better position to distribute, or absorb, a loss. It is difficult to conclude that loss distribution arguments have influenced only the facts found and not, to some degree, the rules applied. However, substantial change in tort rules has not occurred. Instead it is the overall involvement of insurers with the system which leads us to conclude that insurance has had a major effect.

\section{Ought Insurance to Have Influence?}

Discussion of whether liability rules and the tort system in general have been influenced by insurance must be distinguished from whether rules should be so influenced. As soon as we start discussing law reform, we cannot focus only upon the distributive effects between the class of victims and the class of wrongdoers. Instead we must also take account of the majority of injured people who are presently left completely outside of the tort system. Whether, for all these people, compensation is better paid via tort liability as opposed to first party loss insurance or state welfare payments depends upon the political, moral and economic prisms through which the question is viewed. ${ }^{63}$ 'Should the state play a greater role in dealing with misfortune?' invites a wide range of responses. The extent that tort system should be seen as only providing corrective and not distributive justice reflects wider political and moral perspectives. ${ }^{64}$ It is, however, essential that that debate be informed by knowledge of what the tort system actually achieves in practice.

Even within a narrower focus, the argument that the reality of insurance and insurability should be taken into account is a very imprecise one. Whose insurability should we focus upon? By what criteria are we to determine who is the 'better' or cheaper insurer when both sides will nearly always be able to purchase cover at some price? By concentrating on insurability we may divert attention from deterrence and whether market forces may have a role to play via tort in affecting risk taking behaviour, although the scope for such a possibility has been much exaggerated often

\footnotetext{
${ }^{63}$ Sugarman op cit.

${ }^{64}$ For a website debate revealing the divisions among tort scholars see the 2003 postings beginning with Harold Luntz at http://www.ucc.ie/law/odg/messages/030723b.htm .
} 
because of its very failure to take into account how insurance actually operates. Description of the influence that insurance has had must therefore be distinguished from the prescriptive effect that others might wish it to have. In contrast to the conclusion we reached above that insurance has had a major influence upon the tort system, and has had at least some part to play upon individual decision making, the view here is that it will not be possible to reach any general agreement on the role that it ought to play.

\section{ANALYSIS OF SPECIFIC AREAS OF TORT LAW}

These general views of the effect of insurance are now considered in the context of specific areas of tort law. Although covering disparate caselaw, this section offers more detailed illustrations of the arguments which have been made previously.

\section{Procedure}

Insurers are closely consulted and involved in making rules of civil procedure. These rules permeate the tort system and bring it to life. The Civil Procedure Rules 1998, eight pre-action protocols, ${ }^{65}$ and fixed costs agreements ${ }^{66}$ were the result of lengthy negotiation between interested parties, and insurers played a major part. In particular, insurers attitudes towards conditional fee agreements and their readiness to embark upon satellite litigation to contest the ability of claimants' lawyers to bring claims has had major effects upon use of tort law. For example, those suffering from industrial disease are now much less likely to obtain representation, and they will find it even more difficult to obtain compensation than they did previously. ${ }^{67}$

\section{${ }^{65}$ http://www.dca.gov.uk/civil/procrules fin/menus/protocol.htm}

\footnotetext{
${ }^{66}$ These agreements were reached following mediation by the Civil Justice Council between what were described as the two sides of the personal injury litigation industry. The Civil Procedure Rules were subsequently amended to reflect the agreements.

${ }^{67}$ It is true that there has been a proliferation of disease claims recently, numbers rising almost threefold from 73,000 in 2002 to 213,000 in 2004 according to Compensation Recovery Unit figures.
} 
Although fee arrangements have been sanctioned which clearly take insurance into account, in a number of other respects the formal rules of procedure have ignored insurance. For example, until they were effectively abolished in 1934, juries were used to a greater or lesser extent to determine tort cases, and there was a rule of practice at the Bar that a jury was not to be told about the insurance position. ${ }^{68}$ This rule countered the fear that liability might be imposed too readily if laymen were aware that an individual defendant was insured. Previously it was said to be difficult to get a fair hearing from a jury especially in a motor accident case. ${ }^{69}$ The rule has no part to play today because the judge, sitting alone, will be aware from his own experience that insurers are likely to be party to the great majority of tort cases that come before him. Commenting upon the old rule one judge said:

“...[T]hose days are long past. Everyone knows that all prudent professional men carry insurance, and the availability and cost of insurance must be a relevant factor ....,"70

Another example of where the legal system refuses to acknowledge the presence of insurance is embedded in the doctrine of subrogation. Standing in its client's shoes, an insurer has a right to defend the claim or bring an action to recoup monies it is liable to pay out under a policy. This involvement in litigation via subrogation is accomplished by using not the name of the insurer itself, but that of its policyholder

However, this is the result of the special compensation rules that have devised for miners' respiratory diseases and vibration white finger. Almost 740,000 of such claims have been registered since 1999, and are said to be "the biggest personal injury schemes in British legal history and possibly the world" according to http://www.dti.gov.uk/coalhealth/01.htm. However, the move to conditional fees for other disease claims has made solicitors much more reluctant to pursue them as acknowledged at recent Association of Personal Injuries Lawyers meetings. For the difficulties traditionally faced by those suffering from disease see J. Stapleton, Disease and the Compensation Debate (Oxford: OUP, 1986).

${ }^{68}$ Discussed by Lord Denning in Post Office v Norwich Union Fire Insurance Soc Ltd [1967] 2 QB 363 at 375. If the rule were breached, the jury could be discharged. Askew v Grimmer (1927) 43 TLR 354.

${ }^{69}$ Scrutton LJ in Gowar v Hales [1928] 1 KB 191 at 197.

${ }^{70}$ Lord Griffiths in Smith v Bush [1990] 1 AC 831 at 858. 
alone. As a result the law reports are replete with what are fictitious actions, and students are often left with little indication of the importance of insurance to the civil system. ${ }^{71}$ The press and public are similarly left in ignorance of the insurance background. This cloak of anonymity has only rarely attracted the criticism it merits. ${ }^{72}$

Procedural problems can be caused by failing to recognise the role of insurers. For example, it may be necessary to serve documents directly upon the defendant himself. The insurance company may not suffice. ${ }^{73}$ In particular, the Motor Insurers Bureau, which administers the reserve funds for motor vehicle accidents involving uninsured or unidentified drivers, has been able take considerable advantage of the technicalities resulting from the requirements of service. ${ }^{74}$ To avoid some of the procedural difficulties, sometimes it has been necessary to create special rules. For example, even though a defendant company is no longer in existence it is now possible for it to be restored to the register of companies solely in order for it to be sued. ${ }^{75}$ Its old insurer cannot then avoid liability for injuries only because it has been dissolved. However, there are difficulties even with this procedure ${ }^{76}$ and further problems are still caused

${ }^{71}$ This includes the ignorant jury who refused to find the named defendant liable because "you sued the wrong people. You should have sued the insurance company.” R. Eggleston, Evidence, Proof and Probability (London: Weidenfeld \& Nicolson, $2^{\text {nd }}$ ed 1983) 73.

${ }^{72}$ But see Hasson, "Subrogation in Insurance Law - A Critical Evaluation” (1985) 5 Oxford J Leg Studies 416.

${ }^{73}$ The position in relation to motor insurance has been improved by the European Communities (Rights Against Insurers) Regulations 2002 (SI No 3061) made pursuant to the Fourth Motor Insurance Directive 2000/26/EC.

74 P.A. Cain, Claims against Uninsured and Untraced Drivers (London: Sweet \& Maxwell, 2003), N. Jervis and J. Dawson, A Practical Guide to the Handing of Motor Insurers' Bureau Claims (London: Butterworths, 2002)

${ }^{75}$ Companies Act 1989 s 141.

${ }^{76}$ The Law Commission, Third Parties - Rights against Insurers Report No 272 (2001), and Lord Chancellor's Department Consultation Paper (2002) http://www.dca.gov.uk/consult/rro/tparties.htm . 
by the fact that an individual defendant and not an insurer is technically the party to the action.

\section{The Duty of Care}

The duty concept acts as the gatekeeper of the law of tort insofar as it determines whether novel claims are to proceed further. Taking into account wider policy factors, judges can rule out claims for which there may be no precedent. Policy concerns such as the danger of encouraging a flood of claims and placing an excessive burden upon defendants have been most discussed in relation to the duty concept. However, judges have examined less often the secondary consequence of such a danger - the difficulty of insuring against a very wide liability. Stapleton argues that such a factor is distinct from the morality of imposing an indeterminate liability, and that insurance difficulties alone have been of little importance in decision making. This is because, firstly, she believes that, where a duty has been found, insurance has only been used as a superfluous additional argument for doing so; and secondly, where a duty has been denied, insurance tends to be ignored even though it may be clear that the defendant could protect himself against the liability.

By contrast, it has been argued that the scope of the duty of care expanded directly in relation to the increasing availability of liability insurance from 1880 , and it contracted following insurance fears after $1984 .{ }^{77}$ In response Stapleton states that this causal connection can only be made in a very broad sense for, although there were several major fluctuations in liability over the century, there was no equivalent ebb and flow of insurance to account for them. As an illustration, the case that heralded the judicial retrenchment of the 1980's may actually have ignored the insurance position. ${ }^{78}$ This is because the decision severely curtailed liability for causing economic loss, even though it was probable that liability insurance was actually

\footnotetext{
${ }^{77}$ Davies op cit.

${ }^{78}$ Murphy v Brentwood DC [1991] 1 AC 378.
} 
available to cover that loss, or would have been made available if required. ${ }^{79}$ Such insurance exists in other European countries. ${ }^{80}$

However, there are cases where insurance has been specifically taken into account. Distribution of loss arguments have been considered particularly relevant where economic loss has been claimed. ${ }^{81}$ In one such case, when considering the general principles to be applied to determine whether a duty of care existed, a judge discussed at length how his decision might be affected by broad views of the economic consequences. ${ }^{82}$ Two specific illustrations of the effect of insurance in a particular case can be given. In the first, a classification surveyor, employed by shipowners, was held to owe no duty of care to those having an interest in the cargo. ${ }^{83}$ In part this was because the court considered their irrecoverable loss was "readily insurable." The second case concerned the liability of a surveyor of property engaged by a mortgagor. He was held liable for his survey to the purchaser of the property who, although not directly commissioning the report, had relied upon it. In preventing the surveyor from disclaiming a duty of care, one judge said that the risk of the surveyor's negligence would be distributed among all house purchasers through an increase in his fees to cover insurance, rather than allowing the whole of the risk to fall upon the one unfortunate purchaser. ${ }^{84}$ These distributional consequences can be hard to assess, and reveal the wide scope for potential discussion. Fearful of this, and in order to limit

${ }^{79}$ Clarke op cit at 277 and 286.

${ }^{80}$ Ibid. Contrast the generally limited provision in European countries described in Van Boom et al, Tort and Insurance Law: Pure Economic Loss (Vienna: Springer, 2004) especially at 200.

${ }^{81}$ See cases cited in S. Deakin, et al op cit at 144 et seq.

${ }^{82}$ Hoffmann J in Morgan Crucible Co v Hill Samuel [1991] Ch 295 at 302.

${ }^{83}$ Marc Rich \& Co v Bishop Rock Marine Co Ltd [1996] AC 211 at 241.

${ }^{84}$ Lord Griffiths in Smith v Bush [1990] 1 AC 831 at 859. 
speculation, other judges have asked for clear evidence to be presented on matters such as uninsurability. ${ }^{85}$

Conflicting judicial views about the relevance of insurance can be illustrated by reference to two recent cases involving injuries suffered when taking part in sport. In the first, insurance was thought relevant to whether a rugby referee owed a duty of care to the players in the game over which he had control. The court accepted that its decision was affected not only by the availability of liability insurance, but also by the countervailing consideration of the ability of the players to take out their own accident insurance. ${ }^{86}$ A duty of care was found, with the insurance position being a 'makeweight,' but relevant, argument. By contrast, in the second case, although again a duty was found, insurance was deemed irrelevant. A duty of care towards a boxer was imposed on the non-profit making Board that governed boxing, and its insurance and financial difficulties that might result were ignored. ${ }^{87}$

Where, as in most cases, insurance is not discussed, a few tort commentators still speculate whether it might help to explain a court decision. For example, it has been held that an ambulance service owes a duty of care to those it has been called to attend. ${ }^{88}$ However, the fire service owes no such duty in responding to its emergency calls. ${ }^{89}$ One textbook comments:

"If there is to be a difference between the cases, it seems better to realise that it lies in the fact that the fire service is primarily concerned with saving property and that imposing liability would tend to enure for

\footnotetext{
${ }^{85}$ Perrett $v$ Collins [1998] 2 L1 Rep 255 at 277, and the dissent of Lord Lloyd in Marc Rich \& Co v Bishop Rock Marine Co Ltd [1996] AC 211.

${ }^{86}$ Vowles v Evans [2003] 1 WLR 1607 at 1614, Van Oppen v Clerk to the Bedford Charity Trustees [1990] 1 WLR 235.

${ }^{87}$ Watson v British Boxing Board of Control [2001] QB 1134 at 1163.

${ }^{88}$ Kent v Griffiths [2001] QB 36.

${ }^{89}$ Capital and Counties plc v Hampshire County Council [1997] QB 1004.
} 
the benefit of subrogated fire insurers who have taken a premium to cover the risk ...."90

By contrast, the person who suffered brain damage as a result of the failure of the ambulance to arrive was unlikely to carry first party insurance against such an injury. It is impossible to disprove the view that insurance may have had an effect upon these decisions, but it can be hazardous to make other than to make a speculative connection as the above textbook writer did. Such connections are not far-fetched; but in the individual case they remain unproven.

\section{Fault, Strict Liability and the Standard of Care}

The standard of care has been said to be affected by insurance because judges have a wide discretion to interpret what may be expected of the reasonable man. They can demand a very high level of care and, in effect, impose strict liability through the fiction of fault. The standard of care can be made more objective by being divorced from the particular circumstances, and excuses, of the defendant, as where a learner driver is held to the standard of care of a fully qualified driver.

Although it is tempting to assert that it is insurance that accounts for these high standards, other explanations are possible. For example, one judge recently acknowledged that the great care required of motorists merely reflected the fact that the car is a very dangerous weapon and the pedestrian very vulnerable. ${ }^{91}$ Moreover, it is clear that the scope of liability does not correspond to the extent of potential protection provided by insurance. Firstly, as a modern example we might note that the standard of care required of doctors has not been stretched to exceptional levels in spite of the availability of insurance or other means to distribute the cost. Secondly, it must be remembered that in the nineteenth century defendants were held liable for extensive damage long before liability insurance became readily available from

\footnotetext{
${ }^{90}$ W. V. H. Rogers, Winfield \& Jolowicz on Tort (London: Sweet \& Maxwell, $16^{\text {th }}$ ed 2002) 143. This echoes the view of Lord Hoffmann in Stovin v Wise [1996] AC 923 at 954.

${ }^{91}$ Russell v Smith [2003] EWHC 2060, and Eagle v Chambers [2004] RTR 9.
} 
around $1880 .{ }^{92}$ The formal rules of tort then offered considerable scope for the imposition of strict liability long before there were ideas that this might be economically efficient or that losses might be channelled into deeper pockets. Although the liability insurance market became well established in the early part of the twentieth century, it was the fault principle, rather than strict liability, that came to dominate the formal law. The loss spreading and insurance rationales of strict liability were largely abandoned by the common law after a landmark case in 1946, which saw the triumph of fault. ${ }^{93}$ Thereafter strict liability could usually only be found where courts labelled as fault those acts which were far from being so in reality. Although statute has imposed some strict liability, it is limited and, apart from in work accident cases, and for some aspects of economic loss, ${ }^{94}$ it has had little practical effect. Insurance therefore has not resulted in the widespread development of rules of strict liability.

The fault principle continues to thrive in spite of the growth of insurance. A claim will fail unless fault is proven no matter how much insurance the defendant carries. For example, no damages are payable as a result of an accident in which the driver dies of a heart attack before the collision occurs, or where the driver is suddenly affected by an illness of which he had no prior knowledge. ${ }^{95}$ Not only will there be no liability in tort, but there can be no claim on any reserve fund. Strict liability has been imposed for many work accidents where statute prescribes the standard of care required. However, it is still possible for a defendant to avoid liability by arguing that the statute requires proof of fault, or that its breach was not the cause of the injury to

\footnotetext{
${ }^{92}$ Its roots can be traced back to the early nineteenth century and marine insurance. However, the major stimulus was provided later in the century as a result of engineering risks and employers liability.

Parsons, "From Accident to Liability - A Brief History of Liability Insurance" (2002) 17 (2) Insurance Research \& Practice 23, W. A. Dinsdale op cit.

${ }^{93}$ Read v Lyons \& Co Ltd [1947] AC 146.

${ }^{94}$ K. M. Stanton, The Modern Law of Tort (London: Sweet \& Maxwell, 1994) chap 17.

${ }^{95}$ Mansfield v Weetabix [1998] 1 WLR 1263
} 
the claimant. A couple of very recent cases illustrate this. The failure to provide a safe working platform as prescribed by statute was held not to be the cause of injury when the claimant fell from the platform as a result of it being deliberately toppled in anger by a workmate. ${ }^{96}$ Similarly, even though an employer supplied safety boots that contained a hole and caused the claimant to suffer frostbite, there was no liability because this was not a risk against which the steel-capped boots were intended to guard. ${ }^{97}$ Although insurance undoubtedly influenced the imposition of strict liability upon employers in the first place, it is but part of a complex mixture of factors determining whether damages will be paid. In many cases the morality behind the fault principle, or the notion of responsibility, has sufficient strength to override the fact that the defendant is insured. Insurance has brought about no sea change in the formal basis of liability and its influence is partial at best.

\section{Causation}

Although drawing a line to liability based on causation is open to wide ranging influences, cases that specifically refer to insurance are few indeed. Even in a major recent case dealing with injury by asbestos where the amounts of compensation at stake were exceptional and policy issues to the fore, insurance was not mentioned. ${ }^{98}$ This has not prevented commentators from suggesting that the hidden hand of insurance might explain the very generous view of causation taken in a number of personal injury cases where liability has been imposed for freak accidents or bizarre results. ${ }^{99}$ However, again the influence of insurance is inconsistent for it is possible to point to cases that have adopted a less generous approach. Some claimants have been

\footnotetext{
${ }^{96}$ Horton v Taplin Contracts [2003] PIQR P12.

${ }^{97}$ Fytche v Wincanton Logistics [2004] ICR 1582.

${ }^{98}$ Fairchild v Glenhaven Funeral Services [2003] AC 32. Morgan, "Lost Causes in the House of Lords" (2003) 66 Modern L R 227 at 282 notes that the sums involved in this case were "staggeringly large" and cites a press release from the construction union UCATT headlined “insurance companies hit for $£ 6$ - $£ 8$ billion."

${ }^{99}$ Cane op cit note 1 at 106.
} 
denied despite their need of compensation, and even though the defendant was not only at fault but also insured.

Insurance has been said to be a factor in certain cases where the causation rules have been applied in a restricted way to provide for only a very limited liability in relation to property damage. ${ }^{100}$ Claimants are much more likely to carry first party insurance for such damage than they are to be insured against personal injury. Lord Hoffmann recently stated:

"Property insurance is relatively cheap and accessible; in my opinion people should be encouraged to insure their own property rather than seek to transfer the risk to others by means of litigation, with the heavy transactional costs which that involves."

However, in the same case Lord Hobhouse denied that insurance should affect principles of liability:

"The argument that insurance makes the rule unnecessary is no more valid than saying that, because some people can afford to and sensibly do take out comprehensive car insurance, no driver should be civilly liable for his negligent driving."

In an earlier case, Lord Denning, following the Hoffmann reasoning, explicitly argued that no liability should be imposed, and there should be a break in the chain of causation, partly because the claimant could have relied on first party insurance against property damage. ${ }^{102}$ In fact, the judge may have been wrong in this for the property had been empty for some time and, as a result, no insurance may have been

${ }^{100}$ For example, the limited liability imposed for damage caused by fire in the USA. J. G. Fleming, An Introduction to the Law of Torts (Oxford: Clarendon Press, $2^{\text {nd }}$ ed 1985) 15, W. L. Prosser, Law of Torts (West Publishing Co: St Paul, $4^{\text {th }}$ ed 1971) 553.

${ }^{101}$ Transco v Stockport Metropolitan Council [2003] 3 WLR 1467. Similarly Lord Diplock in Photo Productions v Securicor Ltd [1980] AC 827 at $851 \mathrm{cf}$ Lord Denning in the lower court who considered that a plaintiff's loss insurance could be cancelled out by a defendant's liability insurance [1978] 1 WLR 856 at 866.

${ }^{102}$ Lamb v Camden LBC [1981] QB 625. 
in force. ${ }^{103}$ The case may illustrate that when courts try to take wider factors into account they may find the position more complex than at first appears. They may lack the technical evidence required, and their speculation about the insurance position may prove quite wrong. ${ }^{104}$

\section{Defences}

It is possible to view certain cases in which courts have refused to apply defences which would deprive the claimant of all or part of the damages as being influenced by the insurance position. For example, the ability to pay is said to account for cases in which the tiredness of a worker which helps to cause his own injury is held not to constitute contributory negligence, and his damages are not then reduced. By contrast, the tiredness which results in injury to another worker, and for which the employer could be vicariously liable, is held to be negligence.

However, courts never refer to insurance specifically in this context, and the argument again depends on cases being determined by hidden factors and accepting that its effect on the law, at best, is partial. On the one hand, insurance may have influenced both judges and Parliament in that they have restricted the scope of the defence of consent in areas where insurance is compulsory. For example, in motor accidents a statute prevents a passenger's claim from being defeated by any express or implied agreement he may have made with the driver. ${ }^{105}$ This means that his claim cannot be defeated by a notice in the vehicle disclaiming any liability. Similarly for work accidents, judges have determined that where an employer is in breach of his statutory duty the claim against him cannot be avoided by pleading that the worker consented to the state of affairs. On the other hand, however, it must be emphasised that contributory negligence continues to be applied frequently in personal injury

\footnotetext{
${ }^{103}$ Lee and Merkin, "Human Action as Novus Actus Interveniens” [1981] New LJ 965.

${ }^{104}$ Clarke op cit 292 notes that information on insurance may be hard to obtain, and argues that the reasons for putting a ceiling on the liability of carriers, for example, do not bear close scrutiny.

${ }^{105}$ Road Traffic Act 1988 s 149.
} 
claims, reducing damages in about a quarter of all cases that are settled. ${ }^{106}$ In a recent case damages were reduced by as much as 60 per cent in spite of the defendant being in breach of statutory duty. ${ }^{107}$ Furthermore, even the defence of consent survives in a handful of cases to defeat a claim from those who are extremely foolhardy, such as the passenger who chose to take a joyride in a plane, rather than a car, with a pilot with whom he had consumed a great deal of alcohol. ${ }^{108}$ The morality of the fault principle is hard to eradicate in such a case, no matter what the level of insurance.

In one case, although consent failed as a defence involving a claim for occupier's liability, warning notices displayed at the behest of the liability insurer were held to be effective to deny a duty of care to a spectator at a motor race. ${ }^{109}$ The case is especially notable for the dissent of Lord Denning who, because of the insurance factor, would have allowed damages. He thought that the insurer's warning notices should have been ineffective because insurers should not be allowed to take the premiums and yet avoid the liability. However, the other judges did not share his analysis. A statute was later passed which today may enable such a claim to succeed. It prevents an occupier of business premises from excluding liability for death or personal injury to visitors. However, an exclusion relating to property damage is allowed if it is reasonable. One of the factors affecting this, and specified in the statute, is the availability of insurance. $^{110}$

\section{Vicarious Liability}

Vicarious liability has been justified on the basis that it enables losses to be borne by those with deeper pockets, and that employers are better placed to make insurance

${ }^{106}$ D. Harris et al, op cit 91.

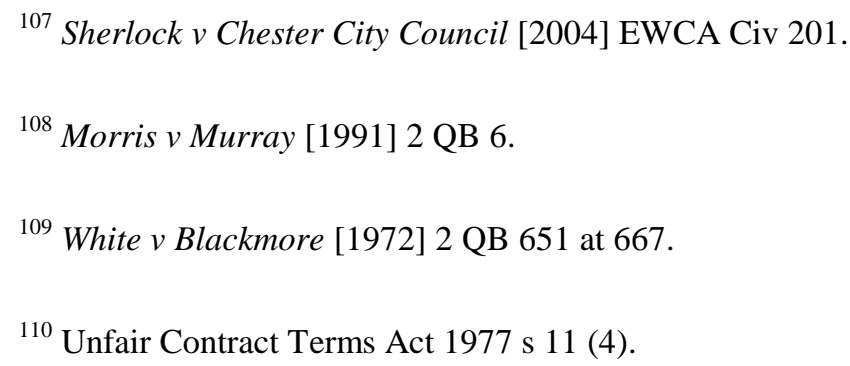


provision. ${ }^{111}$ Although these justifications may help account for some aspects of the liability, again they will not suffice to justify the full scope of the rule. For example, there is usually no vicarious liability for the acts of independent contractors even though the needs of the claimant and the ability of the employer to insure may be the same. Nor is there liability if the employee acts outside the course of his employment. Even where recent decisions appear to impose a stricter liability, judges do not refer to insurance as a factor. ${ }^{112}$ It cannot be asserted that there is a direct correlation between the availability of insurance and the imposition of vicarious liability when the basic rule is subject to such major exceptions for which insurance cannot account. Stapleton stresses this point, and argues that the wide approval of the vicarious liability limits undermines the relevance of insurability as a factor in tort law. ${ }^{113}$ However, although it cannot be viewed as a sole factor, insurance cannot be discounted as an influence upon the expansion in liability.

In a vicarious liability case in 1957 a court notably refused to take insurance into account and this led to measures being taken to avoid its result. ${ }^{114}$ The insurer of the employer found vicariously liable successfully reclaimed the damages for which it was responsible from the negligent employee who had caused the accident. Although the action was brought via subrogation in the name of the employer, it was pursued against the employer's wishes. Employers generally were opposed to such recovery by insurers. Together with trade unions, they considered that it would be bad for industrial relations if responsibility for shop-floor accidents were to be transferred to

${ }^{111}$ P.S. Atiyah, Vicarious Liability in the Law of Torts (London: Butterworths, 1967) 22 - 28.

${ }^{112}$ For example, liability has recently been imposed for sexual assaults carried out by a warden on boys at a boarding school in Lister v Hesley Hall [2001] 2 WLR 1311, and for the deliberate stabbing of the claimant by a nightclub steward away from his place of employment in Mattis v Pollock [2003] 1 WLR 2158. Glofcheski, “A Frolic in the Law of Tort: Expanding the Scope of Employers' Liability” (2004) 12 Tort LR 18.

${ }^{113}$ Op cit at 828.

${ }^{114}$ Lister v Romford Ice Co [1957] AC 555. Williams, "Vicarious Liability and the Master's Indemnity" (1957) 20 Modern L R 220 and 437. 
uninsured employees in this way. As a result, after the case they came to a private agreement with insurers' representatives that subrogation would not be used in this way again. ${ }^{115}$ The full effects of the fault system were therefore abandoned in practice. Although this was achieved without judicial assistance, ${ }^{116}$ the result is that it is insurers, and never employees, who pay the tort bill.

Insurance has recently been discussed in cases involving the potential liability of those who employ independent contractors. In order to take advantage of the usual rule which would result in no liability provided that it was reasonable to employ the contractor in question and steps were taken to ensure his competence, it was argued that the employer should inquire whether the contractor carried liability insurance. In one case a majority of the Court of Appeal agreed that such an inquiry should be made even if the contractor appeared otherwise competent, at least if he were to perform hazardous work. However, the scope of this duty was severely limited: it did not extend to checking the terms of the policy itself, or to discovering whether the policy was still current. As a result, on the facts of the case, the occupier was held not liable for a negligent fairground contractor who had recently allowed his liability insurance to expire. $^{117}$

In this case Sedley LJ strongly dissented from the view that there should be a duty to check for insurance in relation to a contractor who, in other respects, may appear reasonable to appoint. He feared that to create an independent duty to check for insurance would be a major extension of liability, and that this should not be done without more detailed information about the social and economic impact. ${ }^{118} \mathrm{He}$ commented that the test for establishing a duty of care was as much a restrictive as an

${ }^{115}$ Gardiner (1959) Modern L R 652.

${ }^{116}$ But see Lord Denning in Morris v Ford Motor Co Ltd [1973] 1 QB 792.

${ }^{117}$ Gwilliam v West Hertfordshire NHS Trust [2003] QB 443.

${ }^{118}$ He received support from the first instance judge in Bottomley $v$ Todmorden Cricket Club [2004] PIQR P18. The Court of Appeal in this case did not find it necessary to determine whether an independent duty arose. 
expansive test, and could be used "to keep in check the tendency of contemporary western tort law to creep towards a situation in which anyone can sue anyone for anything." Sedley's argument may have had some effect for, in a later case, the Court of Appeal restricted the relevance of insurance to liability. It decided that, in the absence of special circumstances, there should be no free-standing duty to check insurance. ${ }^{119}$ On the facts of the case, therefore, there was no liability for the negligence of a contractor who had been approved by the local authority to carry out the task in question.

\section{Assessment of Damages}

Contrary to the impression that may be gained from a tort textbook, it is quantum rather than liability that is the more important issue for a practitioner. Insurers are far more likely to contest the amount of damages claimed rather than whether there has been a breach of duty. Arguments that the defendant did not cause the injury or owed no duty of care are rare indeed. Too little attention has been paid by academics to the damages award. It should be a focus of concern not only when the efficacy of the tort system as a whole is being discussed, but also when the justice of any tort rule is being scrutinised. The debate about the influence of insurance upon tort similarly reflects too little concern about the damages award.

It is clear that, at least in cases of serious personal injury, "the size of damages awards ... is explicable only on the basis that judges are influenced by the widespread presence of insurance." ${ }^{120}$ This is a major point. The extraordinarily high level of damages all paid in one lump sum is the feature of the tort system that distinguishes it from welfare and other compensation systems. Liability insurance enables tort to espouse its distinctive rhetoric: it purports to make an assessment of loss that is not only tailored to the individual claimant, but sufficient to restore the position before

\footnotetext{
${ }^{119}$ T Naylor v Payling [2004] EWCA 560.

${ }^{120}$ P. Cane op cit note 1 at 204.
} 
injury took place. These claims are greatly overstated, ${ }^{121}$ and yet form much of the reason for tort's existence. Without a mechanism to distribute the cost of imposing liability, it would rarely be worth assessing damages in the way we do at present in serious injury claims. Without insurance it is doubtful whether the tort system would survive at all. Insurance in this sense provides the lifeblood of tort.

In recent years major changes have been made to the assessment of damages, and many of these are predicated upon payment being made either by insurers, or other large self-insured bodies. The assessment of damages has become ever more precise. Actuarial and forensic accountancy evidence has become commonplace. Such matters as the discount rate for early receipt of damages, ${ }^{122}$ the interest rate on delayed payment, ${ }^{123}$ and the inflation factor enabling past awards to be compared with those of the present day have all been more closely linked to the wider financial world. In a few serious injury cases lump sum payment has been replaced in part by a structured settlement, a reform prompted, manufactured and, until recently, controlled by insurers and insurance intermediaries. ${ }^{124}$ However, courts now have the power to order that damages take this periodic form even if the parties object. ${ }^{125}$ It is impossible

${ }^{121}$ The system fails to achieve its high ideals and, within its own terms, often under-compensates the more seriously injured claimants. Lewis et al, "Court Awards of Damages for Loss of Future Earnings: An Empirical Study and an Alternative Method of Calculation” (2002) 29 J of Law \& Society 406, and "Loss of Earnings Following Personal Injury: Do the Courts Adequately Compensate Injured Parties?" (2003) 113 Economic J 568.

${ }^{122}$ Law Commission, Structured Settlements and Interim and Provisional Damages (1994) Report No 224. Damages Act 1996. Wells $v$ Wells [1999] 1 AC 345. The Lord Chancellor's reasons for changing the rate appeared on the LCD website when he considered the matter afresh in July 2001. See http://www.lcd.gov.uk/civil/discount.htm .

${ }^{123}$ Law Commission, Pre-Judgement Interest on Debts and Damages (2004) Report No 287.

${ }^{124}$ Lewis, “Structured Settlements: An Emergent Study” (1994) 13 Civil J Q 18. R. Lewis, Structured Settlements: The Law and Practice (London: Sweet \& Maxwell, 1993) and I. Goldrein and M. de Haas (eds), Structured Settlements: A Practical Guide (London: Butterworths, 2nd ed 1997).

${ }^{125}$ The Courts Act 2003 s 100. 
to conceive of such developments - involving continuing lifetime obligations to make increasing payments - if it were not for the fact that individuals almost never pay tort damages themselves. The argument here is that it is not easy to divorce these changing rules on assessment and payment of damages from the fact that it is insurers who run the tort system.

Insurance monies can have had a direct effect upon the assessment of damages. In examining the extent that damages take account of collateral benefits, whether deriving from private or public sources, a trend can be discerned towards preventing claimants obtaining double compensation. ${ }^{126}$ For example, in one of a series of cases which deducted various types of social security benefit from damages, a judge recognised the reality that damages are met from insurance premiums, and to allow a claimant to recover twice, at the expense of insurers, could not be justified. ${ }^{127}$ Following the institution of statutory scheme in 1990, social security benefits are now recovered by the state from damages awards. Insurers are required to deduct benefits from any tort compensation they pay, and reimburse the state. However, no account is taken of any private insurance from which the claimant benefits ${ }^{128}$ unless it relates to a policy paid for by his employer alone and to which the claimant has made no contribution. ${ }^{129}$ It is therefore still common for over-compensation to take place. For example, in two thirds of the cases where negligence causes death, the estate benefits from receipt of life insurance monies in addition to tort damages. ${ }^{130}$ Private insurance is therefore usually ignored by the tort system, whereas public insurance is now almost always deducted from damages, and this has reduced the incentive to sue in tort.

${ }^{126}$ R. Lewis, Deducting Benefits from Damages for Personal Injury (Oxford: OUP, 1999) para 1.14.

${ }^{127}$ Lord Bridge in Hodgson v Trapp [1989] 1 AC 807.

${ }^{128}$ Bradburn v Great Western Railway Co (1874) LR 10 Exch 1. See Lewis ibid chap 8.

${ }^{129}$ Pirelli General Plc v Gaca [2004] 3 All ER 248.

${ }^{130}$ Law Commission, Personal Injury Compensation: How Much is Enough? (1994) Report No 225 para 13.8 . 
Apart from this example, the extent that insurance influences damages in particular cases, as opposed to the system in general, is much less clear. In the USA, individual damages awards have clearly been affected by insurance policy limits. There is evidence that lawyers do not pursue claims beyond these limits in order to obtain "blood money" from defendants personally. ${ }^{131}$ However, in the UK the policy limits for a claim are almost never relevant, ${ }^{132}$ and therefore it is less easy to see the precise effect of insurance cover. As in other areas, judges have expressed different views concerning the relevance of insurance and this results in much uncertainty. Their diversity of approach can be illustrated by three leading appellate cases. Although they all mention insurance, in only one of them was there any detailed discussion of the wider effects on society of substantially increasing damages, and in the first of them the relevance of insurance was emphatically denied.

In this first case damages were sought for the care freely given by a spouse to his loved one following her serious injury. ${ }^{133}$ It was established law that such a claim could be made even though the husband did not charge his wife for the help he gave her. However, the complicating factor was that the wife's injury had been caused by the husband's own negligence. He was thus both tortfeasor and carer. The court held that his wife could not succeed in her claim for the cost of care that he had freely given. A tortfeasor could not be expected to pay twice for the injury by not only giving the care, but then also having to pay for it. The claimant had argued that this ignored the reality that it was the husband's insurer that would pay, not the husband himself. However, the House of Lords rejected the relevance of insurance, and its views were supported by the Law Commission for the "danger otherwise is that decisions as to

${ }^{131}$ Baker, "“Blood Money, New Money and the Moral Economy of Tort Law in Action” (2001) 35 Law \& Soc Rev 275.

${ }^{132}$ As illustrated by Great North Eastern Railway v Hart [2003] EWHC 2450, a case arising from the Selby rail disaster. A negligent motorist caused a railway accident resulting in his insurer being liable to various claimants for a total of $£ 22$ million.

${ }^{133}$ Hunt v Severs [1994] 2 AC 350. 
where liabilities should be imposed will be made on the basis of who happens to be insured." 134

In the second of the cases, the court again took a conservative line with regard to the relevance of insurance when it substantially increased compensation to allow more precisely for the return on investment of a lump sum award of damages. Actuarial evidence showed that previously claimants had been under-compensated because they had been expected to obtain an unrealistic rate of interest. To pay for the increase in damages the court recognised that insurance premiums would have to rise. "Whether this was something which the country can afford is not a subject on which your Lordships were addressed. So we are not in a position to form any view as to the wider consequences." 135 Any change to the rule that the defendant had to pay damages in full could only be made by Parliament "which, unlike the judges, is in a position to balance the many social, financial and economic factors which would have to be considered...."136

By contrast, in the final case, evidence of the wider consequences of raising damages for non-pecuniary loss was presented to the court, and had considerable effect upon the outcome. ${ }^{137}$ Although involving questions of social policy, the level of damages was not thought a matter for Parliament alone. However, the court drew a distinction between its role in a claim for pecuniary as opposed to non-pecuniary loss: for pecuniary loss, the court was only required to make the correct calculation, and

134 Law Commission, Damages for Personal Injury; Medical, Nursing and other Expenses (1999) Report No 262 para 3.74. This did not prevent the Commission from recommending that the rule established by the case should be reversed.

${ }^{135}$ Lord Lloyd in Wells $v$ Wells [1999] 1AC 345 at 373.

${ }^{136}$ Lord Hutton ibid at 405. Similarly Lord Scarman in Lim v Camden Area Health Authority [1980] AC 174 at 187 considered the effect of higher awards on insurance premiums and the NHS matters for Parliament.

${ }^{137}$ Heil v Rankin [2001] QB 272 criticised by Lewis, “Increasing the Price of Pain” (2001) 64 Modern L R 100. 
economic consequences were irrelevant; whereas for non-pecuniary loss, the court was concerned with what was fair, just and reasonable, and the impact upon society was then a relevant factor. The court was to avoid setting damages "at a level which would materially affect the cost of living or disturb the current social pattern...."138 As a result it was important to consider how the insurance industry might be affected by any change. In addition, the consequences for the National Health Service (NHS) in paying for the effects of clinical negligence had to be considered. Various parties submitted written evidence to the court giving details of the effect on insurance premiums of a change in the way damages are assessed. They also dealt with the consequences for the NHS if its resources were to be depleted by increasing awards of compensation. Although these matters were discussed in general terms in the judgement itself, there was no examination of the detailed calculations. Nevertheless a decision was reached which was broadly favourable to defendants: although damages for pain and suffering were increased by up to a third in the most serious injury cases, no increase was made for the mass of claims involving minor injury. Compared to the Law Commission's proposal for a substantial increase in damages for a much broader range of cases, ${ }^{139}$ this change caused insurers little difficulty. The Commission had attached much less importance than the court to the wider consequences for society and had not considered cost to be relevant. Although the court tried to confine the wider ranging arguments to non-pecuniary loss cases, it was directly influenced by the impact of any change in assessment upon insurance.

Wider ranging factors which might influence damages for personal injury were also discussed in a case which considered whether such awards must be considered as comparators when damages for defamation are assessed. ${ }^{140}$ In deciding that

\footnotetext{
${ }^{138}$ Diplock LJ in Wise v Kaye [1962] 1 QB 638 at 669. Lord Denning feared small insurance companies could be ruined if premiums were increased and he was concerned about their wider effect upon "the body politic" in Fletcher v Autocar and Transporters Ltd [1968] 2 QB 322 at 335, but see Salmon LJ at 363 .

${ }^{139}$ Law Commission, Damages for Personal Injury: Non-Pecuniary Loss (1998) Report No 257.

${ }^{140}$ The Gleaner Co Ltd v Abrahams [2003] 3 WLR 1038 at 1053.
} 
comparison need not always be made, Lord Hoffmann noted that damages for personal injury, unlike those for defamation, are almost always paid by insurers or out of public funds and, as he stated elsewhere, "spread across the whole community by an intricate series of economic links." ${ }^{141}$ The exemplary and deterrent effects of such damages are minimal or non-existent. The total sums paid out by the personal injury system are very large and have an effect upon the economy as a whole. As a result, he argued, the amounts awarded depend to some extent upon what society can afford to pay the victim. By contrast, these considerations have little part to play when damages for defamation are assessed.

\section{INSURANCE AND STATUTE}

\section{Insurers' Lobbying and Influence upon Legislation}

A wide range of legislation going far beyond liability concerns can affect insurers. They formed their own trade association in 1917 partly in order to respond to potential changes in the law. ${ }^{142}$ The Association of British Insurers (ABI) has since grown to such an extent that, with one exception, it is now more than twice the size of any other trade association. ${ }^{143}$ With an annual budget of over $£ 20$ million, it has been very effective in putting forward the industry's point of view. The regulatory framework of insurance reflects the success of the ABI in arguing for forms of self-regulation in lieu of statutory controls, and for exemption from general legislation that might otherwise apply. The clearest example of this is the last minute exemption of insurance policies from domestic legislation dealing with control of unfair contract terms, a result

\footnotetext{
${ }^{141}$ Dimond v Lovell [2000] 2 WLR 1121 at 1133.

${ }^{142}$ Its history is traced in W.L. Catchpole and E. Elverston, BIA Fifty (Stockport: P. H. Press, 1967).

${ }^{143}$ M. Boleat, Trade Association Strategy and Management (London: Association of British Insurers, 1997) 21. The exception is the National Farmers' Union.
} 
described by the former Director General of Fair Trading as "amazing."144 Because of such influence, insurance remains the least regulated of contracts.

An example of the ABI pressing its case in a forthright manner is where it issued a press release just before an appellate hearing was due to take place. In the release it threatened insurers' withdrawal from a particular market in the event of the court finding liability. ${ }^{145}$ More effective has been its regular lobbying of government ministries. One insurance commentator has even suggested that, internationally, institutions such as the ABI "see themselves as governing governments." ${ }^{146}$ In addition to lobbying ministries, the ABI has ensured that its case is heard in Parliament. Until 1997 one in ten Members of Parliament declared a financial link with the insurance industry, ${ }^{147}$ although this figure has been halved for the current Parliament. ${ }^{148}$

The $\mathrm{ABI}$ is organised so as to respond to all government proposals to change the wide areas of law with which it is concerned. In 1998 the government announced that no proposal for regulation which has an impact upon businesses would be considered by ministers without a "regulatory impact assessment" being carried out. Rather than being just another bureaucratic requirement, the new procedures offer business and

${ }^{144}$ G. Borrie, The Development of Consumer Law and Policy - Bold Spirits and Timorous Souls (London: Stevens, 1984) 110.

${ }^{145}$ Layard, "Insuring Pollution in the UK” [1996] Environmental Liability 17 at 18.

${ }^{146}$ R. V. Ericson et al, Insurance as Governance (Toronto: University of Toronto Press, 2003) at 151. See also R. V. Ericson and A. Doyle, Uncertain Business: Risk, Insurance and the Limits of Knowledge (Toronto, University of Toronto Press, 2004).

${ }^{147}$ Clarke op cit 281.

${ }^{148}$ The author's examination of the Register of Members' Interests in February 2004 revealed that only eight members of the House of Lords declared an insurance interest, one being membership of Lloyds. Only fifteen Members of Parliament declared any connection with insurance companies, although a further ten recorded that they were current members of Lloyds and nine others that they were former members. 
industry a major opportunity to influence the policy and legislative process. ${ }^{149}$ Parliamentary Bills are now accompanied by impact statements assessing the financial costs and benefits of the measures being proposed. In drawing up such statements civil servants are directed to consult widely. Twenty or so bodies are specifically named, one of them being the ABI. ${ }^{150}$ As a result, it is automatic for the ABI to be asked to estimate the effect of proposed reforms on insurance premiums. Insurability is therefore now a relevant consideration whenever statutory changes affecting tort are being considered. Impact statements have given insurers a more formal and public opportunity to make representations to government, but it is doubtful whether this has given them much more influence than they had previously. This is because their most effective representations continue to be exercised in private, behind closed doors. ${ }^{151}$

One illustration of the effectiveness of such private lobbying is the overturning of a Law Commission recommendation that a particular financial formula be used to set the discount rate in assessing damages. (This rate makes allowance for the investment return upon lump sum damages). In the Damages Act 1996 the Commission's recommendation was replaced by a power given to the Lord Chancellor to change the rate as he saw fit. However, this discretionary power was not exercised for some time, and when a rate was eventually set it was less favourable to claimants than if the Commission's formula had been used. The Opposition spokesman in Parliament noted that the change in the Act was "mightily convenient to the insurance industry" and commented that it was the result of "whispering in appropriate ears." effectiveness of this private lobbying is difficult to monitor, and has received only

\footnotetext{
${ }^{149}$ C. Miller, Political Lobbying (London: Politico's, 2000) 251. More generally see M. Rush, Parliament and Pressure Politics (Oxford: Clarendon Press, 1990), W. Grant, Pressure Groups, Politics and Democracy in Britain (Hemel Hempstead: Philip Allan, 1989).
}

${ }^{150}$ Cabinet Office, Better Policy Making: A Guide to Regulatory Impact Assessment (2003) http://www.cabinet-office.gov.uk/regulation/scrutiny/ria-guidance.pdf .

${ }^{151}$ See Boleat, op cit chaps $7-8$ and especially $61-4$.

${ }^{152}$ Lewis, "Lobbying and the Damages Act 1996: 'Whispering in Appropriate Ears"” (1997) 60 Modern L R 230. 
limited attention from public lawyers. It reveals "a hidden dimension of the law which many lawyers may prefer to leave decently covered."153

Finally, we should note that insurers' lobbying is partly responsible for the misleading portrayals of the tort system that appear in the media. ${ }^{154}$ Here there is space for but one example: insurers have been far too ready to assert that the periodic "crises" in premium rates are attributable to changes in tort law rather than structural factors within the industry itself. ${ }^{155}$ Insurers are responsible for much of the public's perception of who benefits from our tort system and at what cost. The climate of reform is very much influenced by them, and in this respect the "compensation culture" debate has not been well informed. ${ }^{156}$

\section{The Influence of Insurance upon Particular Tort Statutes}

Statute has been affected not only by the lobbying of insurers on specific matters, but also, in a more general way, by developments in insurance provision. As with caselaw, it can be argued that new legislative rules reflect the tort system's ability to distribute the cost of injury via insurance. The influence has been said to be clearer in

${ }^{153}$ C. Harlow and R. Rawlings, Pressure through Law (London: Routledge, 1992) 60.

${ }^{154}$ For an excellent analysis, see W. Haltom and M. McCann, Distorting the Law: Politics, Media and the Litigation Crisis (London: University of Chicago Press, 2004).

${ }^{155}$ Cane, "Liability Rules and the Cost of Professional Insurance (1989) 14 Geneva Papers on Risk and Insurance 347, and the Office of Fair Trading, An Analysis of Current Problems in the UK Liability Insurance Market (London, 2003). For analysis of the instability of liability insurance markets see Parsons, "Moral Hazard in Liability Insurance" (2003) 28 (3) Geneva Papers on Risk and Insurance.

${ }^{156}$ Contrast F. Furedi, Courting Mistrust: The Hidden Growth of a Culture of Litigation in Britain (London: Centre for Policy Studies, 1999) with E. Lee et al, Compensation Crazy: Do We Blame and Claim Too Much? (London: Hodder \& Stoughton, 2002) and the Better Regulation Task Force, Better Routes to Redress (London, 2004). The latter, a Government report, concludes that the compensation culture may be a myth, but the public's misperception of it results in real and costly burdens. 
relation to statute than caselaw. ${ }^{157}$ However, others might argue that among the relatively few statutes that deal directly with tort, there are examples of legislation, such as that dealing with occupier's liability, which take little notice of the incidence or potential scope of liability insurance.

By contrast, certain legislative measures can only be explained by reference to the insurance background. For example, one statute exempts from liability any mother causing injury to her unborn child. However, it is subject to an exception where the injury results from the mother's negligent driving of a motor vehicle, and the mother then can be sued. ${ }^{158}$ Although this Act generally reflects a desire to prevent disputes among family members, its effect is limited in that one area where insurance against liability is compulsory. This exclusion of motor vehicle liability cannot merely be coincidental.

Similarly the reform which abolished the rule which prevented actions between husbands and wives has been explained by the need to access insurance funds where a road accident had occurred. ${ }^{159}$ Under that legislation a stay of action may be ordered by a court where no substantial benefit would accrue to either husband or wife, the intention being that this power would be exercised in situations where no insurance existed. The spread of insurance provision is also said to account for a series of statutes which have expanded the scope of liability such as those enabling actions to be brought against the estates of deceased tortfeasors, ${ }^{160}$ dissolved companies, ${ }^{161}$ or by claimants who are partly at fault themselves. ${ }^{162}$ One statute familiar to all tort students explicitly takes insurance into account for it declares that, in determining whether a

${ }^{157}$ Clarke op cit 283.

${ }^{158}$ Congenital Disabilities (Civil Liability) Act 1976.

159 Law Reform (Husband and Wife) Act 1962.

${ }^{160}$ Law Reform (Miscellaneous Provisions) Act 1934.

${ }^{161}$ Companies Act 1989 s 141.

${ }^{162}$ Law Reform (Contributory Negligence) Act 1945. 
notice is sufficient to exclude liability, the court must have regard to the availability of insurance. ${ }^{163}$

\section{CONCLUSION}

This article has argued that insurance has had a profound effect upon tort and in particular upon the system of personal injury litigation. The influence of insurers upon the everyday practical operation of that system is readily apparent. In addition, they clearly have opportunity and regularly seek to influence the development of legislation affecting liability. Much more difficult to assess is the potential for insurance to affect the outcome of individual claims. Proving that the facts of cases have been moulded to fit the deeper pocket of insurers cannot be done by resort to the law reports alone, but it remains the suspicion of many a practitioner. Although it is easier to assess the influence of insurance upon the rules of tort, rather than the facts found in individual cases, the picture is by no means clear. On the one hand certain rules, such as those discussed in the statute section immediately above, clearly reflect the distributional consequences of insurance. In addition, if the focus changes from establishing liability to assessing damages the general influence may be more apparent. On the other hand, there remain large areas of tort law where the rules appear unaffected by insurance. The conclusion reached earlier in the article was that, at best, the influence of insurance upon the common law rules is only partial. Instead, it is with regard to the system as a whole - whether involving statutory or common law rules, fact finding, or everyday operation - that insurance can be seen as of vital importance. It is the lifeblood of the system.

${ }^{163}$ Unfair Contract Terms Act 1977 s 11 (4). 